\title{
Giant protistan parasites on the gills of cephalopods (Mollusca)
}

\author{
Norman McLean ${ }^{1}$, F. G. Hochberg ${ }^{2}$, George L. Shinn ${ }^{3}$ \\ ${ }^{1}$ Biology Department, San Diego State University, San Diego, California 92182-0057, USA \\ ${ }^{2}$ Department of Invertebrate Zoology, Santa Barbara Museum of Natural History, 2559 Puesta Del Sol Road, Santa Barbara, \\ California 93105, USA \\ ${ }^{3}$ Division of Science, Northeast Missouri State University, Kirksville, Missouri 63501, USA
}

\begin{abstract}
Large Protista of unknown taxonomic affinities are described from 3 species of coleoid squids, and are reported from many other species of cephalopods. The white to yellow-orange, ovoid cyst-like parasites are partially embedded within small pockets on the surface of the gills, often in large numbers. Except for a holdfast region on one side of the large end, the surface of the parasite is elaborated into low triangular plates separated by grooves. The parasites are uninucleate; their cytoplasm bears lipid droplets and presumed paraglycogen granules. Trichocysts, present in a layer beneath the cytoplasmic surface, were found by transmission electron microscopy to be of the dinoflagellate type. Further studies are needed to clarify the taxonomic position of these protists.
\end{abstract}

\section{INTRODUCTION}

Cephalopods harbor a diversity of metazoan and protozoan parasites (Hochberg 1983). In this study we used light and electron microscopy to characterize a group of unusual parasites that are found on the gills of numerous species of pelagic cephalopods, but which apparently have never been described. We identify them as large Protista of unknown taxonomic affinities bearing trichocysts of the type that is characteristic of a wide variety of dinoflagellates.

\section{MATERIALS AND METHODS}

Two coleoid squid Moroteuthis robusta were collected in 1982 from the vicinity of the Friday Harbor Laboratories, San Juan Island, Washington, USA. The first specimen (dorsal mantle length, DML, $=100.5 \mathrm{~cm}$ ) was netted in June by a local fisherman. The second specimen $(\mathrm{DML}=127 \mathrm{~cm})$ was found in July in an advanced state of decomposition on a beach. The parasites were fixed in $3 \%$ glutaraldehyde (Ladd) in $0.1 \mathrm{M}$ phosphate buffer $(\mathrm{pH} 7.3)$ with $0.35 \mathrm{M}$ sucrose (room temp. $1 \mathrm{~h}$ ), rinsed briefly in buffer with sucrose, and postfixed on ice in $1 \%$ osmium tetroxide in $0.1 \mathrm{M}$ phosphate buffer ( $\mathrm{pH}$ 7.3) with $0.35 \mathrm{M}$ sucrose (1 h). These specimens were embedded immediately in epoxy resin (see below). One specimen each of the coleoid squids Abralia trigonura and Histioteuthis dofleini were trawled near Oahu, Hawaii, in March, 1980. Gill parasites from the former were fixed in formalin; those from the latter were fixed in osmium tetroxide. Parasites from both were stored in $70 \%$ ethanol until 1982, then osmicated as described above and prepared for light microscopy (LM), transmission electron microscopy (TEM) or scanning electron microscopy (SEM).

Specimens for sectioning were dehydrated in an ethanol series, transferred through 3 changes of propylene oxide, and embedded in epoxy resin. Parasites from the first specimen of Moroteuthis robusta were originally embedded in Spurr's medium. Because difficulties were encountered with the resin during sectioning, the embedding medium was removed with methyl ethyl ketone (Fullam). The specimens were dehydrated in a methanol series, then transferred through ethanols to propylene oxide, and were reembedded in Medcast (Pelco). All other parasites were embedded directly in Medcast. For LM, $1 \mu \mathrm{m}$ sections were stained in $1 \%$ methylene blue in $1 \%$ borax. For TEM, silver sections were stained in saturated aqueous uranyl acetate for $12 \mathrm{~min}$, and in $0.1 \%$ lead citrate for 3 min; they were examined with a Philips 300 transmission electron microscope.

For SEM, doubly fixed specimens were dehydrated in an ethanol series, transferred through 2 changes of 
dimethoxypropane, and critical-point dried in $\mathrm{CO}_{2}$. They were attached to stubs with Double Stick Scotch Tape, coated with $\mathrm{Au} / \mathrm{Pd}$, and examined with a JEOL JSM-35 scanning electron microscope.

Measurements of whole parasites were made on fixed, embedded specimens. Measurements of trichocysts were from electron micrographs

For comparison with trichocysts of the cephalopod parasites, we also examined trichocysts of the freeliving dinoflagellate Gonyaulax catenella. These were fixed as indicated above for the Moroteuthis robusta parasites, and embedded in Medcast.

\section{RESULTS}

Protists of the type described here have been found (by F. G. H.) on the gills of many species of cephalopods in addition to those examined in the present study: the squids Heteroteuthis hawaiiensis, Pyroteuthis addolux, Pterygioteuthis microlampas, Chiroteuthis picteti, Ctenopteryx sicula, Octopoteuthis nielseni and the octopus Eledonella pygmaea from the central North Pacific Ocean off Hawaii; the squid Abraliopsis felis, Histioteuthis heteropsis, Chiroteuthis calyx, Gonatopsis borealis, Gonatus sp., Berryteuthis magister, Galiteuthis sp., the octopus Japatella diaphana and the vampire squid Vampyroteuthis infernalis from the eastern North Pacific Ocean; and the squid Lolliguncula brevis from the Gulf of Mexico. The parasites are obviously common in pelagic cephalopods.

When the mantle cavity is exposed, the cystlike parasites are easily visible to the naked eye. Their color varies from white to yellow-orange depending on the host species. They are partially embedded within small pockets on the surface of the gills. Although fixed to the gills at this stage of the life cycle, the parasites are easily removed. They occur along the full length of the gill on both the outer and inner demibranchs, between the gill lamellae and on the exposed surfaces. At present there is no evidence that they cause necrosis, although the holdfast penetrates the gill tissue.

\section{External morphology}

The parasites from all 3 species of squids are similar in morphology. They are ovoid in shape, and most of the surface is elaborated into low triangular plates. The latter are arranged in groups around numerous foci (Fig. 1 to 3). The number of plates per focus varies from 4 to 7 . The holdfast, or area that attaches to the host, is located on one side of the large end; it lacks plates and bears 2 small papillae, each with an opening at the apex (Fig. 2). The tapered end of the parasite bears an elongate pore of unknown function (Fig. 4).

Parasites from the different species of squids differ from one another in details of the plates and in size. Shallow indentations on all sides of some plates of the Histioteuthis dofleini parasite (Fig. 1) are distinctive. The plates of the Moroteuthis robusta parasite are relatively smooth and raised into short ridges at each corner (Fig. 3). The grooves between plates are broad and shallow compared with some of the grooves of the H. dofleini parasite (Fig. 1). Parasites from Abralia trigonura have flat, smooth plates, although fracturing and exfoliation due presumably to formalin fixation raise the possibility that this is an artifact. Parasites from $M$. robusta $(l=1.62 \mathrm{~mm} \pm 0.23 \mathrm{~mm}$ standard deviation, $w=1.05 \mathrm{~mm} \pm 0.19 \mathrm{~mm}$ standard deviation, $\mathrm{n}=40$ ) were somewhat larger than those from $A$. trigonura $(\mathrm{l}=1.10 \mathrm{~mm}, \mathrm{w}=0.80 \mathrm{~mm}, \mathrm{n}=1)$, and much larger than those from $H$. dofleini $(l=0.56 \mathrm{~mm}, w=$ $0.36 \mathrm{~mm}, \mathrm{n}=1$ ).

\section{Internal morphology}

Sections reveal that the parasites are unicellular. A single large nucleus is located centrally in cross sections (Fig. 5). It has a relatively electron-lucent flocculent matrix and numerous basophilic bodies. The cytoplasm is liberally supplied with lipid droplets and with electron-dense granules that appear to be paraglycogen. The cytoplasm is covered by a wall that gives the plates their integrity; lobes of cytoplasm extend into the convolutions of the wall (Fig. 5). Fixation of the cytoplasm and nucleus was poor in all cases, which suggests that the wall is resistant to penetration by the reagents utilized. The cytoplasmic surface is immediately underlain by a layer of trichocysts which are perpendicular to the extracellular wall, and which in some specimens were remarkably well preserved. No substantive differences were found between the trichocysts of the squid gill parasites and those of the freeliving dinoflagellate Gonyaulax catenella (see below).

The trichocysts are rod-shaped (approximately 1.7 $\mu \mathrm{m}$ long and $0.3 \mu \mathrm{m}$ wide) and bound by a dense

Fig. 1 to 5. Fig. 1. Protist from Histioteuthis dofleini. Note triangular plates arranged in groups around numerous foci, shallow indentations on all sides of plates, and narrow grooves between plates. Scale bar $=100 \mu \mathrm{m}$. Fig. 2 . Protist from $\mathrm{H}$. dofleini. Note holdfast area bearing 2 small papillae, each with an opening (arrowhead) at the apex. Scale bar $=100 \mu \mathrm{m}$. Fig. 3 Protist from Moroteuthis robusta. Note relatively smooth plates raised into short ridges at each corner, and broad grooves between plates. Scale bar $=100 \mu \mathrm{m}$. Fig 4 . Elongate pore at tapered end of protist from $M$. robusta. Scale bar $=10 \mu \mathrm{m}$. Fig. 5 . Cross section of protist from $H$. dofleini. Note lobes of cytoplasm extending into convolutions of the wall. g: groove between plates; $\mathrm{n}$ : nucleus; arrowheads: wall that gives plates their integrity. Scale bar $=50 \mu \mathrm{m}$ 

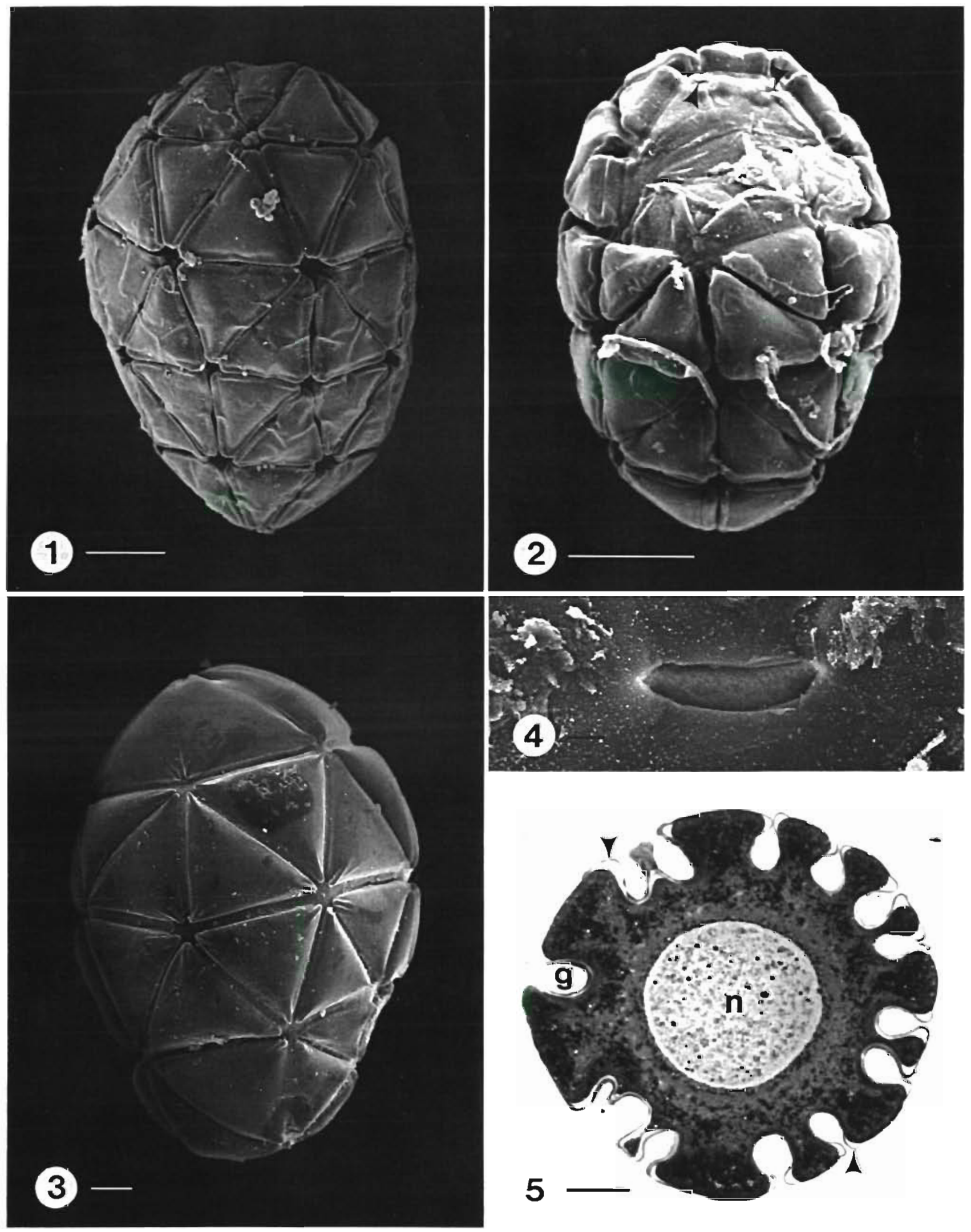

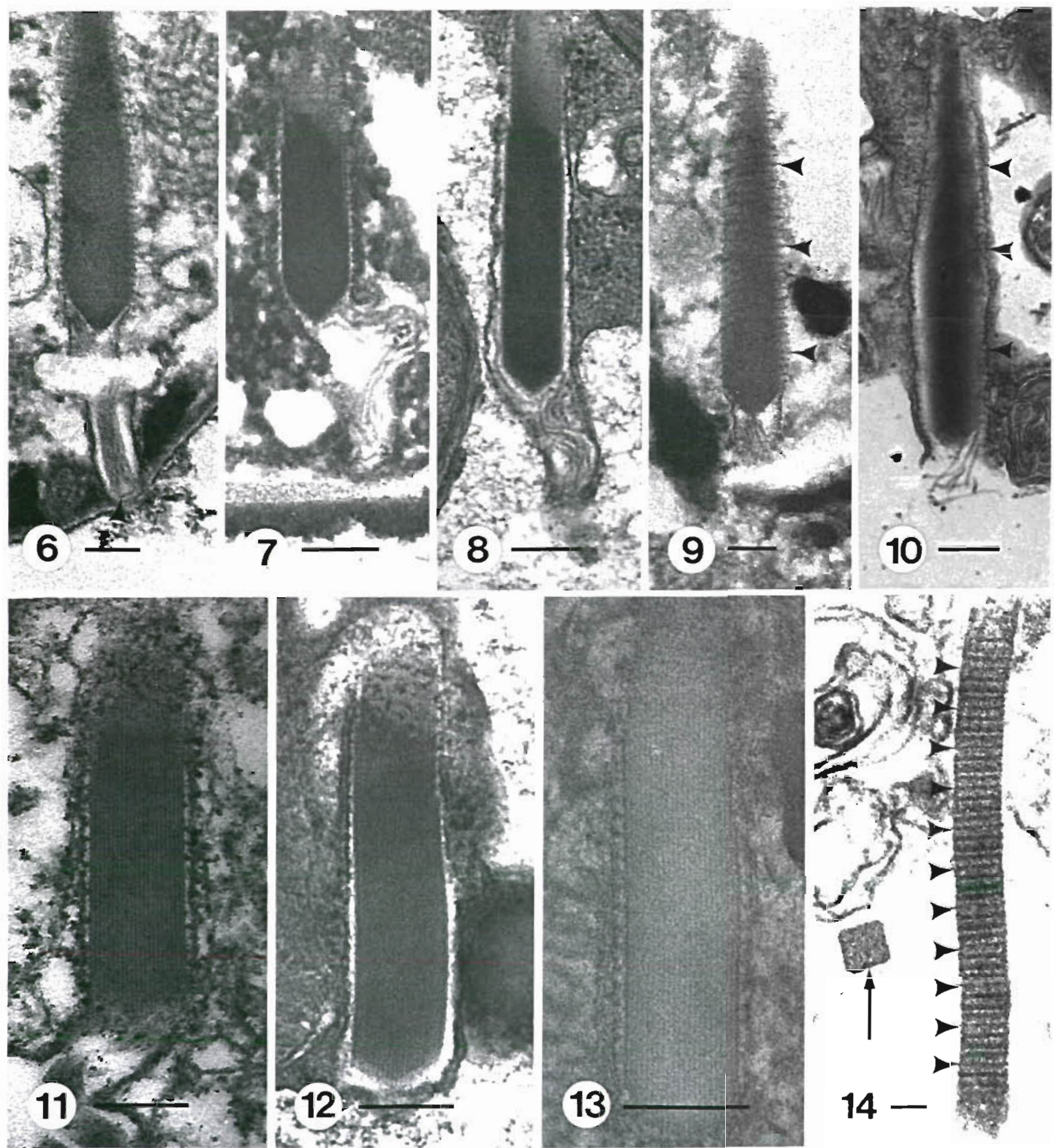

Fig 6 to 13 Trichocysts Scale bars $=200 \mathrm{~nm}$. Fig 6 to 8 Note electron-dense core with conical head and group of filaments. Fig 6 Protist trom Moroteuthis robusta Arrowhead dense plaque Fig 7 Protist from Abralia trigonura. Fig. 8. The dinoflagellate Gonyaulax catenella Fig 9 Protıst from $M$ robusta Arrowheads. hoops in trichocyst membrane. Fig. 10. The dinoflagellate $G$ catenella Arrowheads hoops in trchocyst membrane Fig 11 to 13 Trichocyst core showing longitudinal periodicity. Fig. 11 Protıst from Histioteuthis doflein $F i g ~ 12$ The dinoflagellate G catenella Fig 13 Protist from M. robusta. Fig. 14. Ejected trichocyst of protist from $M$ robusta At nght, longitudinal section Arrowheads indicate transverse periodicity. Arrow: cross 
membrane. The latter encloses an electron-dense core that has a conical head, and a group of filaments that extend from the head to several dense plaques near the limiting membrane of the parasite (Fig. $6 \& 7$ ). The core and filaments of trichocysts from parasites of Moroteuthis robusta (Fig, 6) and Abralia trigonura (Fig. 7) have notably similar counterparts in trichocysts of the dinoflagellate Gonyaulax catenella (Fig. 8). The membrane limiting each trichocyst bears hoops (Fig. 9 \& 10), which measure $30 \mathrm{~nm}$ between centers in the $M$. robusta parasite (Fig. 9), and $23 \mathrm{~nm}$ in the dinoflagellate (Fig. 10). A longitudinal periodicity of the core was occasionally well preserved (Fig. 11 to 13), measuring, between centers of the longitudinal members, $9.3 \mathrm{~nm}$ in the Histioteuthis dofleini protist (Fig. 11), $10.5 \mathrm{~nm}$ in the dinoflagellate (Fig. 12), and $8.8 \mathrm{~nm}$ in the protist from $M$. robusta (Fig. 13). Ejected trichocysts were found in parasites from the decayed $M$. robusta that was acquired in July 1982. The threads are square in cross section (about $60 \mathrm{~nm}$ per side); the longitudinal axis displays a transverse periodicity of $55 \mathrm{~nm}$ (Fig. 14).

\section{DISCUSSION}

The external morphology of the parasites provides few clues to their taxonomic position. The lack of external cilia or flagella does not exclude the possibility that they are ciliates or flagellates, as encysted stages of these groups typically lack motile organelles. Given that the hosts are highly mobile, it is probable that the life cycle includes an as yet undiscovered motile stage. We found no individuals in the process of producing swarmers, however. The wall, with its elaborate plates, was always fully differentiated. Nevertheless, variation in the size of individuals on a single host suggests that the organisms grow at this stage of the life cycle.

The reliability of trichocysts as taxonomically definitive structures has not been established. There is, however, a striking uniformity of trichocyst morphology throughout the Dinophyceae (Dragesco \& Hollande 1965, Bouck \& Sweeney 1966, Leadbeater \& Dodge 1966, Sweeney \& Bouck 1966, Dodge \& Crawford 1968, Messer \& Ben-Shaul 1969, Soyer 1969, 1970, 1978, Hausmann 1973, 1978, Cachon \& Cachon 1974. Hollande 1974, Sweeney 1978, Hollande \& Corbel 1982, Wedemayer \& Wilcox 1984). The unusual OxyIrhis marina is the only dinoflagellate whose trichocysts are distinctive in ultrastructure, but the taxonomic status of this species is in doubt (Triemer 1982). The trichocysts of other groups of flagellates are, in contrast, significantly different (Hovasse et al. 1967, Mignot 1967, Mignot \& Hovasse 1973, Brugerolle 1985). The morphological similarity between the trichocysts of the squid parasites and those of dinoflagellates supports our designation of the organelles as dinoflagellate' trichocysts. The similarity extends to the appearance of trichocysts that have discharged with necrosis: discharged trichocysts from parasites of our necrotic Moroteuthis robusta closely resemble those of Peridinium westii, in which organelles have degenerated due to aging of cultures (Messer \& Ben-Shaul 1971). We assume that the trichocysts are synthesized by the parasites. Trichocysts of dinoflagellates are not known to be acquired and stored by predators (e.g. as are nematocysts by predators of cnidarians). This possibility has not been discounted, however, and could lead to an erroneous taxonomic designation.

Most dinoflagellates are much smaller than the squid parasites, although the planktonic Noctiluca miliaris reaches $1.2 \mathrm{~mm}$ in diameter (Trégouboff \& Rose 1957), and trophonts of parasitic dinoflagellates are as large as $0.67 \mathrm{~mm}$ (Becker 1977). The presence of an apical pore also suggests that the parasites may be dinoflagellates, and furthermore, that they are a cyst stage (Dodge 1985). The nucleus of dinoflagellates typically contains visible organized chromosomes, which are not evident in our specimens, but this is not a routine feature (Hollande \& Corbel 1982).

Amoebae typically lack trichocysts, but an estuarine amoeba described by Page (1979) contains a trichocystlike body. This differs from the trichocysts reported here in that longitudinal striae are not visible in the mature stage, the core head is not conical, and the organelle membrane does not bear hoops. Thus it is unlikely that the gill parasites are sarcodines.

Present evidence argues against the possibility that the squid gill parasites are the cysts of ciliates, although many squids harbor extremely large endosymbiotic ciliates in the digestive tract (Hochberg unpubl.). Cysts of ciliates typically exhibit nuclear dualism (Grimes 1973, Walker \& Maugel 1980, Walker et al. 1980), whereas the gill parasites appear to have a single large nucleus. Unlike those described here, mature trichocysts of normal ciliates lack a conical end on the core, longitudinal periodicity, and filaments, and furthermore the trichocyst membrane lacks hoops (Yusa 1965, Bradbury 1966, Bannister 1972, Esteve 1974, Anderer \& Hausmann 1977, Peck 1977, Njine \& Didier 1980). The core of pre-trichocysts of Paramecium caudatum has very fine longitudinal striations that are lost as the trichocysts develop (Yusa 1963), and trichocysts of mutant $P$, aurelia have very fine longitudinal striations (Pollack 1974). The large mature trichocysts of normal Paramecium spp., however, are quite unlike those described in the present study. A tiny bundle of filaments is present in the trichocyst of Drepanomonas dentata (Hausmann \& Mignot 1975), but the accompanying 4 dense rod-like structures appear to be unique. A bounding membrane in Neobursaridium 
gigas bears large hoops (Dragesco 1968), but the core has a transverse periodicity and the tip is dense as in Paramecium spp.

This paper brings attention to a group of giant protistan parasites on the gills of cephalopods, and provides ultrastructural evidence that their trichocysts are similar to those of dinoflagellates. Differences in size and plate morphology of parasites obtained from different species of cephalopods suggest that many species of these protists exist. Further information about the cytology and life stages is needed and will require study of more fresh hosts of various ages, and, perhaps, culturing of the parasites.

Acknowledgements. We are grateful to Dr A. O. Dennis Willows for use of research facilities at the Friday Harbor Laboratories, University of Washington, and to Dr Eugene N. Kozloff and Dr Albert K. Sparks for valuable comments.

\section{LITERATURE CITED}

Anderer, R., Hausmann, K. (1977). Properties and structure of isolated extrusive organelles. J. Ultrastruct. Res. 60: 21-26

Bannister, L. H. (1972). The structure of trichocysts in Paramecium caudatum. J. Cell Sci. 11: 899-929

Becker, C. D. (1977). Flagellate parasites of fish, In: Kreier, J. P. (ed.) Parasitic Protozoa, Vol. 1. Academic Press, New York, p. 357-416

Bouck, G. B., Sweeney, B. M. (1966). The fine structure and ontogeny of trichocysts in marine dinoflagellates. Protoplasma 66: 205-223

Bradbury, P. C. (1966). The fine structure of the mature tomite of Hyalophysa chattoni. J. Protozool. 13: 591-607

Brugerolle, G. (1985). Des trichocystes chez les Bodonidés, un caractère phylogénétique supplémentaire entre Kinetoplastida et Euglenida. Protistologica 21: 339-348

Cachon, J., Cachon, C. (1974). Comparaison de la mitose des Péridiniens libres et parasites à propos de celle des Oodinium. C. r. hebd. Séanc. Acad. Sci., Paris 278: $1735-1737$

Dodge, J. D. (1985). Atlas of dinoflagellates. Ferrand Press, London

Dodge, J. D., Crawford, R. M. (1968). Fine structure of the dinoflagellate Amphidinium carteri Hulbert. Protistologica 4: $231-242$

Dragesco, J. (1968). A propos de Neobursaridium gigas Balech. 1941: sténothermie, inclusions, ultrastructure des trichocystes. Protistologica 4: 157-168

Dragesco, J., Hollande, A. (1965). Sur la présence de trichocystes fibreux chez les Péridiniens; leur homologie avec les trichocystes fusiformes des Ciliés. C. r. hebd. Séanc. Acad. Sci., Paris 260: 2073-2076

Esteve, J.-C. (1974). Cytochimie ultrastructurale du trichocyste in situ chez Paramecium caudatum. Protistologica 10:371-378

Grimes, G. W (1973). Differentiation during encystment and excystment in Oxytricha fallax. J. Protozool. 20: 92-104

Hausmann, K. (1973). Cytologische Studien an Trichocysten. VI. Feinstruktur und Funktionsmodus der Trichocysten des Flagellaten Oxyrrhis marina und des Ciliaten Pleuronema marinum. Helgoländer wiss. Meeresunters. 25: 39-62
Hausmann, K. (1978). Extrusive organelles in protists. Int. Rev. Cytol. 52: 197-276

Hausmann, K., Mignot, J.-P. (1975). Cytologische Studien an Trichocysten. X. Die zusammengesetzten Trichocysten von Drepanomonas dentata Fresenius 1858. Protoplasma 83: $61-78$

Hochberg, F. G., Jr. (1983). The parasites of cephalopods: a review. Mem. Nat. Mus. Victoria 44: 109-145

Hollande, A. (1974). Etude comparée de la mitose syndinienne et de celle des Péridiniens libres et des Hypermastigines infrastructure et cycle évolutif des Syndinides parasites de Radiolaires. Protistologica 10: 413-4.51

Hollande, A., Corbel, J.-C. (1982). Ultrastructure, cycle évolutif et position systématique de Caryotoma bernardi Holl. et Enj. (Dinoflagelles Oodinides), parasite endocapsulaire des Thalassicolles (Radiolaires). Prototistologica 18 123-133

Hovasse, R., Mignot, J.-P., Joyon, L. (1967). Nouvelles observations sur les trichocystes des Cryptomonadines et les ' $R$ bodies' des particules kappa de Paramecium aurelia killer Protistologica 3: 241-256

Leadbeater, B., Dodge, J. D. (1966). The fine structure of Woloszynskia micra sp. nov., a new marine dinoflagellate Br. phycol. Bull. 3: 1-17

Messer, G., Ben-Shaul, Y. (1969). Fine structure of Peridiniurn westii Lemm, a freshwater dinoflagellate. J. Protozool. 16 $272-280$

Messer, G., Ben-Shaul, Y. (1971). Fine structure of trichocyst fibrils of the dinoflagellate Peridinium westii. J. Ultrastruct. Res. 37: 94-104

Mignot, J.-P. (1967). Structure et ultrastructure de quelques chloromonadines. Protistologica 3: 5-24

Mignot, J.-P., Hovasse, R. (1973). Nouvelle contribution à la connaissance des trichocystes: les organites grillagés d' Entosiphon sulcatum (Flagellata, Euglenida). Prototistologica 9: 373-391

Nijine, T. Didier, P. (1980). Étude ultrastructurale des ciliés du genre Leptopharynx Mermod, 1914. Protistologica 16: 155-166

Page, F. C. (1979). Vexillifera armata n. sp. (Gymnamoebia, Paramoebidae), an estuarine amoeba with distinctive surface structures and trichocyst-like bodies. Protistologica 15: $111-122$

Peck, R. (1977). The ultrastructure of the somatic cortex of Pseudomicrothorax dubius: structure and function of the epiplasm in ciliated protozoa. J. Cell Sci. 25: 367-385

Pollack, S. (1974). Mutations affecting the trichocysts in Paramecium aurelia. I. Morphology and description of the mutants. J. Protozool. 21: 352-362

Soyer, M.-O. (1969). Etude ultrastructurale des inclusions paracrystallines intra-mitochondriales et intra-vacuolaires chez Noctiluca miliaris S. Noctilucidae et observations concernant leur rôle dans la genèse des trichocystes fibreaux et muqueux. Protistologica 5: 327-334

Soyer, M.-O. (1970). Les ultrastructures liées aux fonctions de relation chez Noctiluca miliaris S. (Dinoflagellata). Z. Zellforsch. mikrosk. Anat. 104: 29-55

Soyer, M.-O. (1978). Particules de type viral et filaments trichocystoides chez les dinoflagellés. Protistologica 14: $53-58$

Sweeney, B. M. (1978). Ultrastructure of Noctiluca miliaris (Pyrrophyta) with green flagellate symbionts. J. Phycol. 14: 116-120

Sweeney, B. M., Bouck, G. B. (1966). Crystal-like particles in luminous and non-luminous dinoflagellates. In: Johnson, F. H., Haneda, Y. (ed.) Bioluminescence in progress. Princeton Univ. Press, Princeton, p. 331-348 
Trégouboff, G., Rose, M. (1957). Manuel de planctonologie Méditerranéenne. Vol. I. Centre National de la Recherche Scientifique, Paris

Triemer, R. E. (1982). A unique mitotic variation in the marine dinoflagellate Oxyrrhis marina (Pyrrophyta). J. Phycol. 18 $399-411$

Walker, G. K., Maugel, T K. (1980). Encystment and excystment in hypotrich ciliates. II. Diophrys scutum and remarks on comparative features. Protistologica 16 525-531

Walker, G. K., Mangel, T K., Goode, D. (1980). Encystment and excystment in hypotrich ciliates. I. Gastrostyla steinii. Protistologica 16: 511-524

Wedemayer, G. J., Wilcox, L. W. (1984). The ultrastructure of the freshwater, colorless dinoflagellate Peridiniopsis berolinense (Lemm.) Bourrelly (Mastigophora, Dinoflagellida). J. Protozool 31-444-453

Yusa, A. (1963). An electron microscope study on regeneration of trichocysts in Paramecium caudatum. J. Protozool. 10: $253-262$

Yusa, A. (1965). Fine structure of developing and mature trichocysts in Frontonia vesiculosa. J. Protozool. 12: 51-60

Responsible Subject Editor: Dr A. K. Sparks; accepted for printing on August 10, 1987 